\title{
Ethical considerations of corporate social responsibility - A South African perspective
}

\author{
B. Ackers* \\ Department of Auditing, College of Accounting Sciences, University of South Africa, P O Box 392, UNISA, 0003 \\ *To whom all correspondence should be addressed \\ ackerb@umisa.ac.za
}

\begin{abstract}
Today, companies are under increasing pressure to implement corporate social responsibility [CSR] programmes that account for the economic, social and environmental impacts of their operations. In addition to companies voluntarily wanting to be seen as responsible corporate citizens, the requirement for CSR reporting is being institutionalised by the King Code of Governance [King III] in South Africa. The application of King III is mandatory for all companies listed on the Johannesburg Stock Exchange [JSE], albeit on an 'apply or explain' basis. King III requires companies to not only disclose their CSR performance, but also to ensure that such disclosures have been independently assured. Irrespective of the underlying reason for companies disclosing their CSR performance and for providing independent assurance thereon, companies are moving away from simplistically applying the cliché attributed to Friedman that "the social responsibility of business was to use its resources to engage in activities that would increase profits". Companies that have traditionally provided financial reporting to shareholders, are now beginning to account for their non-financial performance to other stakeholders as well. This paradigm shift requires those charged with company governance and reporting (including accounting professionals usually associated with financial reporting), to re-examine their morals, values and ethical beliefs.
\end{abstract}

\section{Introduction}

Global climate change is rapidly becoming the defining issue of our time (Kirk, 2008; Ryghaug, Sørensen \& Næss, 2011). The need for the human race (and by implication for corporations) to deal with the challenges of corporate social responsibility [CSR] in order to avoid an impending ecological collapse (Wim, Kirchgeorg, Griffiths, Linnenluecke \& Günther, 2011), is succinetly articulated in the following statement: "If we insist on ruining the planet, we have to stop claiming we're a superior species" (Berliant, 2009). Corporations are however, expected to demonstrate responsible corporate citizenship to their stakeholders, while still providing an acceptable return to shareholders. One of the emerging challenges facing contemporary corporations is a need to account for what may often be the unintended consequences of business operations. However, the relative topicality of CSR - and especially the different corporate motivations and perspectives - produces varying interpretations (Aras \& Crowther, 2009) and inconsistent implementation.

However, despite its topicality, the principle of CSR responsiveness is not universally accepted. For example, Nobel Prize-winning economist Milton Friedman (1970) argued that the social responsibility of business was to use its resources to engage in activities that would increase profits, while operating within society's predefined rules and norms (Kok, van der Wiele, MeKenna \& Brown, 2001: 287). By contrast, Freeman (1984) introduces stakeholder theory by suggesting that businesses are responsible to yarious groups within society, with a legitimate interest in a corporation and its activities. Freeman posits that it is not enough for corporations to only account to their shareholders, but they should similarly account to their broader stakeholders as well, albeit from an instrumental perspective (Aras \& Crowther, 2009; Bebbington, Larrinaga \& Moneva, 2008: 339-341).

The King Report and the King Code on Governance for South Africa [King III] were released in 2009 and became effective from 1 March 2010. King III is driving balanced corporate reporting by advocating for the disclosure of both financial (annual financial statements) as well as nonfinancial (CSR or sustainability reports) information. The voluntary nature of King III and the 'apply-or-explain' principle complicates the decision-making, requiring corporate management to re-examine their priorities within the context of the often conflicting interests of shareholders and the expectations of the broader stakeholder community.

The shift from shareholder primacy (Kok et al., 2001; 287) to stakeholder responsiveness (Fassin, 2009: 113), requires companies to change their paradigm to one based on deliberate moral and ethical decision-making. Business ethics deals with concepts that describe and explain factual states of affairs, such as managerial motivation, corporate accountability structures and the relationships between ethical behaviour and financial performance (empiricism, or the 'is' of economic affairs) (De Cremer, van Dick, Tenbrunsel, Pillutla \& Murnighan, 2011). Although not necessarily grounded in business practices, business ethics 
deal with ideas guiding what should be done (normativism, or what corporations 'ought' to do) (Donaldson \& Dunfee, 1994: 252-253).

The ethical approach to CSR essentially argues against morally indifferent business practices, favouring the social advantages of morally sensitive stakeholder management practices and expansive public policy. Stakeholders expect corporate ethical behaviour to extend beyond mandatory legal compliance, with ethical managers engaging in impartial moral reflection that extends beyond the law. Windsor (2006; 99) suggests that corporate ethical responsibility lies along a continuum between mandatory compliance (economic and legal) and desirable philanthropy (prudent or voluntary). Whereas corporations may be motivated to engage in and report on responsible CSR practices, either for economic or moral reasons, the real motivation is more likely to have been a combination of the two. Combining an economic motivation (including instrumentalism and legitimacy) and an ethical CSR base is collectively categorised as the political economy of CSR (Sadler \& Lloyd, 2009).

Irrespective of whether the motivation for CSR activities and disclosure is due to economic (instrumental theory), or ethical reasons (being the right thing to do), or even simply to comply with prevailing legislation and regulations, this article examines the ethical underpinnings of CSR. It should therefore become clear that effective engagement in CSR practices requires corporate role players to understand the philosophical ethical dimensions. However, corporate management, often including the accountants who may be responsible for all corporate reporting (including nonfinancial reporting), often do not have the necessary appreciation of the philosophical dimensions required to effectively discharge their duty of accountability, especially with regard to the broader stakeholders.

Until fairly recently, the ethical dimension of business was regarded as being a specialist philosophical field, with little guidance provided to business people and academics. Therefore, despite the ethical component of business not being new, it was usually excluded from mainstream business literature and relegated to specialist publications. This article is not intended for accomplished ethicists or moral philosophers, but to provide business academia, many of whom are grappling with this new dimension, with a brief overview of the fundamental principles of ethics, morality and values that are necessary to enable the board of directors and management to adopt and implement an effective CSR policy and plan. This particularly applies to the members of the accounting profession who are often required to provide balanced reporting on the non-financial aspects of corporate activity. As the CSR movement contimues to gain momentum, this article will provide the insights necessary to understand the emerging CSR phenomenon.

For contextual purposes, this conceptual article provides an overview of CSR, the ethics of CSR, ethical dissonance and the role of corporate leadership. Understanding these elements provides corporations with important insights on becoming responsible corporate citizens by meeting the CSR expectations CSR expectations of stakeholders. Despite the conceptual nature of this article, empirical quantitative data are introduced to illustrate the different corporate motivations for the adoption of responsible CSR practices.

\section{Study approach and methodology}

This article is intended to provide an appreciation of the dynamics and challenges facing business and accounting practitioners (as well as academies) that may not necessarily have had any previous formal exposure to moral philosophy and ethics. In this regard, the King III requirement for corporations to not only disclose their CSR performance, but also to have these disclosures independently assured, has resulted in increased involvement by the accounting profession in the CSR domain. While this article has universal applicability, it is particularly relevant to the preparers of company reports. Traditionally, members of the accounting profession employed within organisations are responsible for preparing or overseeing the preparation of corporate reporting.

This article therefore has particular relevance for the accounting profession, where despite an increasing involvement in CSR-related issues, the formal accounting education and training regimen has historically not considered the non-financial information or the ethical dimensions of business. Instead the focus has been on developing the capacity of accountants to account for and to audit financial information. As a result, the approach adopted for this article is to conceptually introduce the CSR phenomenon. As previously indicated, the parties usually responsible for all corporate reporting often do not have the necessary competencies to fully discharge this responsibility, especially with regard to the disclosure of non-financial information. Adopting and implementing a CSR approach require deliberate choices to be made. This conceptual study therefore links CSR and ethics by considering the impact of moral philosophy and ethics on CSR practices. Thereafter, the primary moral and ethical frameworks are explored, followed by a discussion on the possible dissonance between the personal values of decision-makers and the pressure exerted on them to behave unethically in order to achieve the corporate objectives. Because the CSR approach adopted by corporations must be implemented by natural persons, the CSR role of corporate leadership is explored.

Despite being primarily conceptual article, the results of a component of a self-administered quantitative survey are provided and discussed to assist in motivating companies to adopt responsible CSR practices. The survey instrument was distributed to a range of potential respondents at the 200 largest Johannesburg Stock Exchange [JSE] listed companies (by market capitalisation) during August 2011. To maximise the response rate, several follow up letters, emails and reminders were sent to potential respondents until May 2012. Despite the complete survey instrument 
consisting of 38 questions, only the responses to some of the demographic questions and one 12-part question probing the reasons for companies disclosing the CSR performance are considered in this article. The survey was administered online with a covering letter sent to potential respondents containing a hyperlink that took respondents directly to the web-based online survey. The survey responses were analysed using descriptive statistics describing the nature of the data (Leedy \& Ormrod, 2005: 257).

\section{Corporate social responsibility (CSR)}

Today's corporations are expected to grapple with the sustainable development equation (i.e. balancing the economic, social and environmental benefits and costs), minimising the adverse impacts of operations and optimising the accruing benefits for the majority of stakeholders, but without significantly compromising the longer-term investment returns to the providers of capital (UNCSD, 2007; Morimoto et al., 2005: 318-319).

Advocates of good corporate citizenship tend to argue in favour of a positive correlation between CSR and corporate financial performance [CFP] (Cacioppe, Forster \& Fox, 2008: 688; Brammer, \& Millington, 2008; Orlitzky, Schmidt \& Rynes, 2003; 404). Other authors argued that any correlation was really as a result of strong CFP providing extra resources that could be applied to CSR activities (Mill, 2006; Eccles, Pillay \& De Jongh, 2008; Yuhei, Aubrey \& Seoki, 2011; 544).

Despite the recent topicality about the responsibility of the corporation in respect of its environmental and social impact, it still remains a relatively contentious global issue (Aras \& Crowther, 2009). Globally, stakeholders are increasingly holding corporations to account for the adverse impacts of their action, or inaction, on society and the environment. It may accordingly be argued that today's corporations should realise that they cannot continue operating their businesses with impunity. Companies should account to their stakeholders about the manner in which they discharge their CSR responsibilities

Conversely, it may be argued that by responding to stakeholder pressures for improved CSR performance (Reuvid, 2007: 355), corporations may merely be extending their conventional raison d'être of profit maximisation. Instrumentally, the goal of targeting stakeholder CSR issues may be to create long-term stakeholder value, while simultaneously enhancing corporate financial and reputational market positioning. Moreover, as globalisation continues to spread, increases the pressure on corporations to acknowledge and assess their broader global CSR responsibilities. Ignoring CSR related issues could have dire consequences for the corporation. CSR represents a strategic dimension that cannot be separated from corporate strategy (Black \& Quach, 2009: 3-8). CSR issues should therefore be incorporated into corporate strategy to ensure its ongoing viability, by anticipating and adapting to changing customer expectations, regulatory shifts, surplus corporate capacity and environmental concerns (Williams \& Zinkin, 2008; 211).

\section{The ethics of CSR}

Ethical decision-making could facilitate strong corporate performance and produce a sustainable competitive advantage, whereas unethical decision-making may result in very different outcomes. These adverse outcomes could include tarnished brands and crippled bottom lines (Allen, 2009). Allen argues that ethical behaviour can appreciate over time to provide lasting value, providing an exponential 'return on ethics'. Allen posits that stakeholders usually invest their trust in corporations long before investing their dollars (or Rands), resulting in trust ranking higher than goodwill on the balance sheet. It should be remembered that the corporate ethical approach adopted impacts the nature, effectiveness and result of any CSR and corporate governance interventions.

Corporations, however, are not usually faced with the extreme positions of 'good' or 'bad', but often are forced to make hard choices from difficult 'good' or even 'bad' alternatives. This was illustrated by Frederick van $\mathrm{Zyl}$ Slabbert who stated that "the hardest choices are not between good and bad, but between good and good, where pursuing one good alternative, means less good in another direction" (Sunter, 1996: 77). This comment supports the philosophical mind shift required, from an exclusive 'absolutist' perspective (where the one perspective is more important than any other), towards a more inclusive "pluralist" view (where there is a little bit of good in everything that tolerates alternative views and continually makes compromises). Similarly, Elkington (1999) advocates difficult trade-offs between the 'triple bottom line' of economic, social and environmental benefits and costs for corporations (Waddock \& Graves, 1997: 303; ICAEW, 2004: 8). By contrast, Carroll (1991) depicts CSR as being a set of defined cumulative responsibilities, not trade-offs. Carroll depicts these responsibilities as a pyramid consisting of four internal subdivisions representing the economic, legal, ethical and philanthropic dimensions. All four responsibility dimensions are morally integrated, with moral managers behaving differently in every dimension (Carroll, 1991: 42). The economic and legal dimensions are appropriately grouped together as the economic motivation, with the ethical and philanthropic dimensions comprising the ethical motivation. Orlitzky et al. (2003: 427) concur by asserting that an either/or tradeoff between CSR and corporate financial performance was not justified by their meta-analysis of 30 years of empirical data. They argue that the relationship is bidirectional and simultaneous, with reputation playing an important role.

Drawing on a composite of moral frameworks instead of utilitarianism, ethical CSR uses the shared principles of moral reflection, broad self-restraint and altruism. Altruism is represented by voluntary contributions to society and stakeholders and may involve uncompensated or even costly contributions to stakeholders, or in favour of general 
welfare. Philanthropy on the other hand, represents a discretionary transfer of wealth to stakeholders. However, self-restraint represents corporate management's intentional moral and/or political choices that avoid exploiting legally unregulated market opportunities (Windsor, 2006: 98).

In economic CSR, philanthropy is regarded as being either discretionary altruism by ill-disciplined managers violating their short-term fiduciary responsibilities to the company, or prudent altruism which considers their fiduciary responsibilities through strategically controlling intrusive public policy. Conversely, ethical CSR promotes altruism as being both socially desirable and morally commendable. Instrumentalism, however, transforms philanthropy beyond prudent altruism into a strategic tool to develop corporate legitimacy, enhance reputation and exploit market opportunities.

\section{Ethics and morality}

Morality and ethics are often used interchangeably (Wines, 2008: 487), tending to be regarded as being synonymous within a corporate context (Carroll, 1991: 44). The original difference between the terms "ethics" and "morality" was simply linguistic (Harper, 2009: 1064), arising from the difference between the Latin and Greek, with each relating to a word meaning 'disposition or custom'. According to Harper (2009), moralis is a Latin translation for the Greek ethikos. While the Greek êthos may refer to the philosophical dimension concerned with character or mores, in Latin it represents moral philosophy. As such, the Latin mos (from which moralis is derived) emphasises a sense of social expectation, while the Greek favours individual character. It is suggested that this represents a difference in emphasis but not necessarily a difference in meaning, emphasising society's expectations.

Morality denotes the collection of moral principles which represent rebuttable rather than absolute rules that guide individual choices, decisions or actions (Wines, 2008: 487). Acting in a moral way, involves doing what is good and right, using self-restraint and discipline, based on accepted social norms (Hendrikse \& Hendrikse, 2004: 145). Ethics, on the other hand, represent the cognitive, analytical, systematic and reflective application of moral principles to complex, conflicting or unclear situations, extending beyond the simple application of individual morals (Wines, 2008: 487).

\section{Ethics}

Corporate accountability, extending to constituencies beyond shareholders, is emerging as a strong theme in business ethics research (Moon, Crane \& Matten, 2003: 19). The study of ethics involves a disciplined inquiry into the basis of morality and law. Ethics are closely linked to the moral frameworks hat provide the basis for choices between right and wrong, good and bad, and acceptable and unacceptable courses of action. From an economic CSR perspective, the most important criteria used to assess corporate ethicality, are whether corporations were breaking the law, whereas a moral CSR perspective positions corporate social responsibility according to how society and the environment are treated (Cacioppe et al., 2008: 697698).

Ethical behaviour includes a sense of honesty, fairness, prudence, respect for and service to others, keeping promises, being truthful and developing business relationships based on the principles of trust and integrity (Cacioppe et al., 2008; 682). More fundamentally though, the study of ethics generally consists of examining right, wrong, good, evil, virtue, duty, obligation, rights, justice, fairness, etc. in human relationships with each other and with other living things. Whereas the phrase "do unto others as you would have done to you" (Cowan, 2004: 9), captures the essence of ethics, at the same time it acknowledges that certain practices may be considered to be morally acceptable in some societies, but may be condemned in others. Such differences question the existence of universally applicable ethical principles, by suggesting that 'situational ethics and morality' are derived from situational social norms. This introduces the concept of relativism, where what is considered right for one person (or society), may not necessarily be right for others (Warren, 2011: 213). Relativism was anecdotally illustrated by the late comedian, Groucho Marx, who reportedly said that "I have my morals and values, and if you don't like those, I have others" (unknown).

\section{Morality}

Morality usually refers to the principles of action, whereas ethics is a broader term that tends to incorporate a range of other moral dimensions as well. It is suggested that the term 'moral' is used to refer to questions of societal rights that are distinct from questions of personal preference and lifestyle (Harper, 2009: 1065).

Some economists tend to use Adam Smith's reference to the "invisible hand" as being evidence of his glorification of self-interest. Coker (1990: 142) however argues that a moral philosopher of Smith's stature, who published the Theory of Moral Sentiments in 1759, would never simply have abandoned the moral laws that govern human behaviour when he published the Wealth of Nations in 1776 , without explicitly explaining the change. According to Coker the two works are complementary, with Smith presupposing the existence of a natural moral law, in terms of which the prudent man improves himself, but without causing harm to others. In the Wealth of Nations, economic man uses the social system to temper man's economic behaviour. Smith therefore places the individualism of the Wealth of Nations within the social system of the Theory of Moral Sentiments. In this regard, it is asserted that the invisible hand was not intended to function outside the social context, but as an integral part of it, with prudent economic man consciously seeking to improve himself while simultaneously promoting social welfare. Coker (1990: 140) suggests that Smith believed that benevolence 
arose from man's inherent inclination to bestow benefits on others. Therefore, while the Wealth of Nations guides resource allocation in a free market system, it also specifies the conditions under which the price system operates effectively (Coker, 1990: 141). Since the invisible hand produces social benefits, to Smith, social welfare was a desirable albeit unintended consequence of capitalist activities (Wan-Jan, 2006: 176). Eccles et al. (2008: 3) suggest that Smith believed that the 'invisible hand' of the market was sufficient to efficiently align the interests of shareholders and society.

\section{Ethical dissonance}

Wartzman (1987) illustrates the dissonance between individual and business decision-making by citing a study of 6000 corporate managers and executives finding that $70 \%$ of respondents had personally experienced pressure to conform and compromise their personal values. Wines (2008: 489) introduces a social dilemma where "good people will do bad things, when they are placed in an environment where contrary actions will threaten their livelihood and their ability to support their dependents". Examples of unethical business practices appear daily in the international, national and local media. Stead, Worrell and Stead (1990: 233) argue that all strategies should have an ethical foundation, with managers recognising that they do not operate within an ethical vacuum, but within a societal context. In an article in the Wall Street Journal, Rick Wartzman argues that even the most morally upright individuals may be prone to becoming dishonest and under certain circumstances could even disregard their civic responsibilities. Moreover, recent corporate scandals confirm that unethical managers cannot even be trusted to fulfil their fiduciary responsibilities (Windsor, 2006: 98).

While individuals may hold particular beliefs, they may act in ways that are inconsistent with their personal values. This incongruence produces a moral crisis that straddles two incompatible ethical positions. To be socially acceptable requires a business ethic to be compatible with the prevailing social ideology (Zenisek, 1979: 362). CSR can therefore be conceptualised as representing the fit between the expectations of society and the real ethics of business. This fit has two dimensions. The first dimension is behavioural and represents the fit between the expectations of society and the actions of business. The second dimension is attitudinal, reflecting the fit between the expectations of society and management's perspective of society's legitimate demands. Whereas the behavioural dimension represents a company's responses to social expectations, the attitudinal dimension represents the ideological component of management's attitudes towards socially responsible corporate behaviours (Zenisek, 1979: 362).

Both the norms that guide ethical behaviour and the perceptions about when and how ethical norms should be applied vary according to personality and socialisation factors. For example, while Machiavellians may contend that ethics are situational and not absolute, business ethics proponents argue that human beings are autonomous moral actors capable of making meaningful choices (Wines, 2008: 484). Basic philosophies influencing ethical decisionmaking include utilitarianism - maximising satisfaction, individual rights and justice (Stead et al., 1990: 234-235); Kantian deontology - principle of generalisability (Pesqueux, 2009: 236); contractualism - agreement by the individuals concerned; virtue ethics - in the context of personal relationships; consequentialism - principle of maximisation (Von der Pfordten, 2012); egoism self-interest (Beekun, Stedham \& Yamamura, 2003). Beekun et al. suggest that these theories may potentially produce conflicting interpretations of what may be considered ethical or unethical, with the most important consequentialist theories being egoism and utilitarianism. Egoism promotes individual self-interest as the primary guiding principle without any corresponding obligation to others, or even to the corporation. In terms of utilitarianism, morality is based on the resultant impact on the majority. Egoism ethicists posit that the altruistic efforts of others are really acts of self-promotion, with individuals only helping others in order to advance their own interests. Stead et al. (1990: 235) argue that moral decisions and actions differ according to two primary ethical ideologies. These are idealism (the belief that ethical behaviour results in good outcomes) and relativism (the belief that moral rules are situational). The challenge faced by corporations (and individuals), lies in which ethical base to choose.

Carroll (1991: 44 48) however, introduces a different perspective by considering stakeholders within the context of three primary ethical approaches. These are immoral, amoral and moral management. Immoral managers are characterised by decisions, actions and behaviours that actively oppose what may be deemed as being 'right' or 'ethical. Immoral management decisions are incongruous with society's accepted ethical norms, actively contradicting what may be considered moral. Immoral managers regard regulation as an impediment to achieving objectives, usually strategically exploiting opportunities for personal or corporate gain. Moral managers on the other hand, tend to have ethical positions that comply with accepted societal norms of ethical behaviour. Moral managers not only demonstrate high standards of professional conduct, they often exemplify leadership on ethical issues. Their orientation tends to consider both the letter and spirit of the law, regarding the law as the minimum acceptable ethical behaviour; preferring to perform well above the regulatory requirements. Without ignoring profitability, the decisions of moral managers are characterised by the sound ethical principles of justice, fairness, human rights, utilitarianism and due process. By contrast, amoral managers are neither immoral nor moral, tending to be insensitive about the impact of everyday business decisions on others. These amoral managers may be oblivious to the harm that their business decisions may have on those with whom the business interacts, albeit unintentionally. Their orientation tends to regard the letter of the law as being their ethical guide. However, there is a group of amoral managers whose actions are intentional, that believe that their ethical 
decisions affect their personal lives and but not their business decisions.

Management understandably want tô know how to pragmatically deal with decisions relating to public policy, social and stakeholder issues that affect corporate resource allocation. Strict application of the fiduciary responsibility rule denigrates moral reflection and treats corporate morality as a 'social bad' (Windsor, 2006; 100). Ethical CSR is only ambiguous when viewed as being rigid; scattered; and lacking the logical rigour underpinning a general principle. Whereas principles are usually broad or vague, and ordered hierarchically in terms of relative weights, rules are generally specific and functional. A narrow economic or instrumentalist conception of CSR is insufficient and counterproductive for both society and the corporation (Windsor, 2006: 101). While moral persons may reflect upon self-restraint, altruism and general welfare, under certain circumstances moral concerns may override legally permitted fiduciary responsibilities. No moral person should therefore rigidly follow a functional rule without reflecting in principled fashion on the origins and effects of the rule.

\section{Leadership ethics}

Moral responsibility is not exerted by the corporation itself, but rather by its individual members. The ethical character of the persons occupying leadership positions therefore directly influence the extent to which sound corporate ethical standards are institutionalised. This is reinforced by King III, principle 1.1 that requires the board to provide effective and ethical leadership (IoD, 2009). Collectively, the CEO and the board of directors (the board) establish the values that inform the corporate culture and decisionmaking policies, underpinning the strategy for corporate risk management and for achieving corporate success. Since the corporate authority structure begins at the top, it is suggested that ethical corporate behaviour should similarly be initiated by the board and executive management. Therefore, while the board is appointed by the shareholders to act on their behalf and in their best interests, the board in turn delegates the responsibility for policy implementation to executive management.

The Board's effectiveness depends on how it sets the "tone at the top' and how desirable behaviour is fostered by 'walking the talk' (Black \& Quach, 2009: 13). Interestingly, KPMG $(2008: 44)$ found that $92 \%(n=229)$ of the top 250 global corporations (G250) include a code of ethics in their CSR reporting. The lack of homogeneity is illustrated by this percentage reducing to $64 \%$ when only considering the top 100 corporations in 27 countries (N100). However, despite these ethical declarations, KPMG found that corporate practices were not necessarily transparent, with only $59 \%$ of the $\mathrm{G} 250$ and $34 \%$ of the N100 corporations reporting on non-compliant incidents with their own codes.

Employees tend to emulate management behaviour. It is therefore increasingly recognised that unethical management behaviour could seriously impair the institutionalisation of the desired corporate ethical culture. Depending on the prevailing circumstances, in order to avoid punitive measures or to capitalise on rewards, managers may choose to either implement or ignore ethical practices. Corporate ethical behaviour may be further influenced by the ethical base to which the corporation subscribes, volatile economic conditions, resource scarcity and stakeholder pressure. An ethical trap may therefore emerge where corporate management must choose between behaving ethically and succumbing to the situational pressures of engaging in unethical practices.

The link between ethicality and profitability is tenuous at best. On the one hand, behaving ethically could increase profitability (e.g. by increasing sales through improved reputation management and enhancing customer perceptions). On the other hand, it could equally decrease profitability (e.g. by increasing costs by installing expensive pollution control systems). Moreover, ethical decisions may profoundly affect the corporation's market positioning and competitiveness, or even facilitate the decision to withdraw from a market for moral reasons, as illustrated by several international corporations to withdrawal from South Africa during the apartheid era. However, while such ethical decisions may initially impair profitability, at the same time it may also enhance a firm's image and accordingly its longterm profitability (Stead et al., 1990: 235-237).

\section{Discussion of the empirical study results}

Since this exploratory article's objective is to explore CSR's ethical dimensions, this section introduces relevant, but limited, primary empirical data extracted from a quantitative survey instrument forming part of a larger study that examined the audit profession's CSR assurance role. Extant research confirms that large listed corporations (Ackers, 2009: 7; Eccles et al., 2008: 11; Jenkins, 2001: 10; Waddock \& Graves, 1997: 308-313; Welman, Kruger \& Mitchell, 2011: 69) have the 'slack resources' to deliberately engage in CSR activities. Therefore, despite the survey instrument being distributed to the 200 largest JSE-listed companies (by market capitalisation), which only represented $53 \%$ of JSElisted companies on 30 April 2012 it represented $99 \%$ of the market capitalisation of the JSE.

The empirical data were analysed using descriptive statistics that describe the nature of the data (Leedy \& Ormrod, 2005; 257) that seeks to understand the way things are (Welman et al, 2011: 23). The results of the seven-point Likert scale survey question relating to the reasons that companies disclose their CSR activities are summarised in table 1 below.

To confirm the validity and suitability of survey respondents to provide meaningful responses, the first demographic question probed the type of organisation represented by the respondents. Since the study sample and population was confined to JSE-listed companies, all 39 respondents appropriately represented ISE-listed companies. To 
understand who the actual survey respondents were, using nominal data, the second question asked respondents to describe their positions within the company. Survey respondents represented executive managers responsible for CSR $(\mathrm{n}=8)$; chief audit executives $(\mathrm{n}=8)$; members of the CSR committee $(\mathrm{n}=4)$; with the broad category "other" including the company secretary $(\mathrm{n}=7)$; the chief financial officer ( $\mathrm{n}=1)$; the CSI senior specialist $(\mathrm{n}=1)$; the sustainability manager $(n=3)$, the sustainability director $(\mathrm{n}=1)$; the manager sustainability reporting $(\mathrm{n}=2)$; the social and labour plan group manager $(n=1)$; the executive assistant for public affairs $(\mathrm{n}=1)$; and the risk and sustainable development manager $(\mathrm{n}=1)$.

Table 1: Reasons companies disclose their CSR activities

\begin{tabular}{|c|c|c|c|c|c|c|c|}
\hline & 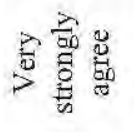 & 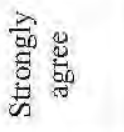 & 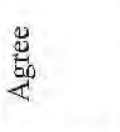 & 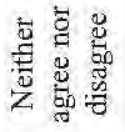 & 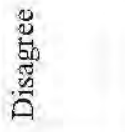 & 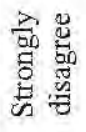 & 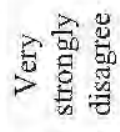 \\
\hline It is required by King III & $\begin{array}{r}38,5 \% \\
(\mathrm{~N}=15)\end{array}$ & $\begin{array}{l}25,6 \% \\
(\mathrm{n}=10)\end{array}$ & $\begin{array}{l}25,6 \% \\
(\mathrm{n}=10)\end{array}$ & $\begin{array}{l}7,7 \% \\
(n=3)\end{array}$ & $\begin{array}{l}2,6 \% \\
(n=1)\end{array}$ & - & - \\
\hline $\begin{array}{l}\text { It demonstrates the company's commitment to being a } \\
\text { good corporate citizen }\end{array}$ & $\begin{array}{l}43,6 \% \\
(\mathrm{n}=17)\end{array}$ & $\begin{array}{c}25,6 \% \\
(\mathrm{n}=10)\end{array}$ & $\begin{array}{l}23,1 \% \\
(n=9)\end{array}$ & $\begin{array}{l}5,1 \% \\
(n=2)\end{array}$ & $\begin{array}{l}2,6 \% \\
(n=1)\end{array}$ & - & - \\
\hline It demonstrates improved transparency & $\begin{array}{l}33,3 \% \\
(\mathrm{n}=13)\end{array}$ & $\begin{array}{l}28,2 \% \\
(\mathrm{n}=11)\end{array}$ & $\begin{array}{l}25,6 \% \\
(\mathrm{n}=10)\end{array}$ & $\begin{array}{l}7,7 \% \\
(n=3)\end{array}$ & $\begin{array}{l}5,1 \% \\
(\mathrm{n}=2)\end{array}$ & - & - \\
\hline It demonstrates improved stakeholder responsibility & $\begin{array}{l}23,1 \% \\
(\mathrm{n}=9)\end{array}$ & $\begin{array}{l}33,3 \% \\
(\mathrm{n}=13)\end{array}$ & $\begin{array}{l}25,6 \% \\
(\mathrm{n}=10)\end{array}$ & $\begin{array}{l}12,8 \% \\
(\mathrm{n}=5)\end{array}$ & $\begin{array}{l}5,1 \% \\
(n=2)\end{array}$ & - & - \\
\hline It demonstrates improved stakeholder accountability & $\begin{array}{l}23,1 \% \\
(\mathrm{n}=9)\end{array}$ & $\begin{array}{l}25,6 \% \\
(\mathrm{n}=10)\end{array}$ & $\begin{array}{l}25,6 \% \\
(\mathrm{n}=10)\end{array}$ & $\begin{array}{l}17,9 \% \\
(\mathrm{n}=7)\end{array}$ & $\begin{array}{l}7,7 \% \\
(n=3)\end{array}$ & - & - \\
\hline $\begin{array}{l}\text { It assists the company to project a positive corporate } \\
\text { image (reputation management) }\end{array}$ & $\begin{array}{r}28,2 \% \\
(\mathrm{n}=11)\end{array}$ & $\begin{array}{l}35,9 \% \\
(n=14)\end{array}$ & $\begin{array}{r}28,2 \% \\
(\mathrm{n}=11)\end{array}$ & $\begin{array}{l}7,7 \% \\
(n=3)\end{array}$ & - & - & - \\
\hline $\begin{array}{l}\text { It provides information on how the company is } \\
\text { managing its CSR related risks }\end{array}$ & $\begin{array}{l}17,9 \% \\
(\mathrm{n}=7)\end{array}$ & $\begin{array}{l}33,3 \% \\
(\mathrm{n}=13)\end{array}$ & $\begin{array}{l}35,9 \% \\
(\mathrm{n}=14)\end{array}$ & $\begin{array}{l}10,3 \% \\
(\mathrm{n}=4)\end{array}$ & $\begin{array}{l}2,6 \% \\
(\mathrm{n}=1)\end{array}$ & - & - \\
\hline $\begin{array}{l}\text { Investors want to know the company's CSR track } \\
\text { record and risks }\end{array}$ & $\begin{array}{l}25,6 \% \\
(n=10)\end{array}$ & $\begin{array}{l}20,5 \% \\
(n=8)\end{array}$ & $\begin{array}{l}35,9 \% \\
(n=14)\end{array}$ & $\begin{array}{l}15,4 \% \\
(n=6)\end{array}$ & $\begin{array}{l}2,6 \% \\
(n=1)\end{array}$ & - & - \\
\hline $\begin{array}{l}\text { Customers want to know the company's track CSR } \\
\text { record }\end{array}$ & $\begin{array}{l}5,1 \% \\
(\mathrm{n}=2)\end{array}$ & $\begin{array}{l}23,1 \% \\
(\mathrm{n}=9)\end{array}$ & $\begin{array}{l}43,6 \% \\
(n=17)\end{array}$ & $\begin{array}{l}15,4 \% \\
(n=6)\end{array}$ & $\begin{array}{l}12,8 \% \\
(n=5)\end{array}$ & - & - \\
\hline It is a useful marketing and PR tool & $\begin{array}{l}15,4 \% \\
(\mathrm{n}=6)\end{array}$ & $\begin{array}{l}23,1 \% \\
(n=9)\end{array}$ & $\begin{array}{l}35,9 \% \\
(n=14)\end{array}$ & $\begin{array}{l}17,9 \% \\
(n=7)\end{array}$ & $\begin{array}{l}7,7 \% \\
(n=3) \\
\end{array}$ & - & - \\
\hline $\begin{array}{l}\text { It positions the company favourably to compete in } \\
\text { global markets }\end{array}$ & $\begin{array}{l}15,4 \% \\
(n=6)\end{array}$ & $\begin{array}{l}33,3 \% \\
(\mathrm{n}=13)\end{array}$ & $\begin{array}{l}25,6 \% \\
(\mathrm{n}=10)\end{array}$ & $\begin{array}{l}15,4 \% \\
(n=6)\end{array}$ & $\begin{array}{r}7,7 \% \\
(n=3)\end{array}$ & - & - \\
\hline
\end{tabular}

Companies may have several reasons for engaging in CSR that will ultimately inform their corporate strategy. A relevant survey question seeking to understand the reasons that companies disclose their CSR performance provided alternative responses that were not mutually exclusive. As a result, respondents were not restricted to only select one response to each question, and could accordingly provide the same responses to different sections of the question. To contextualise the corporate motivations for disclosing CSR performance, the responses reflected in the table above, are described under the following categories:

- Regulatory compliance:

Despite King III being a voluntary code of governance, since the JSE regulations specifically require all JSElisted companies to apply the King III principles or explain why they have not done so; it may be argued that King III compliance is a de facto mandatory reporting requirement for all JSE-listed companies. In this regard, since the study universe was confined to JSE-listed companies, King III can be regarded as constituting a mandatory regulation with which JSElisted companies should comply. In this regard, the overwhelming majority of respondents clearly indicated that regulatory compliance was a significant motivation.
- Ethical reasons:

Ethical reasons for disclosing CSR performance are primarily related to the expectations of society that companies will do the right thing. This category demonstrates the company's commitment to responsible corporate citizenship, improved stakeholder responsibility and accountability, and improved corporate transparency. The overwhelming majority of respondents indicated that the decision to report CSR performance was strongly motivated by ethical reasons.

- Instrumental reasons:

Instrumental reasons for disclosing CSR performance relate to corporations engaging in CSR practices for the benefit of the corporation, primarily driven by shareholder primacy. This category represents the perspective that CSR reporting assists the reporting company project a positive corporate image (reputation management), because:

- it provides information on corporate risk management relating to CSR,

- investors, customers and suppliers want to know the company's CSR track record,

- CSR disclosures are a useful marketing and public 
relations $[\mathrm{PR}]$ tool, and

- CSR disclosures position the company favourably to compete in global markets. This motivation was cynically illustrated by one respondent commenting that "legislation and public sentiment drive companies to display a positive social impact, even if this is for window dressing".

From the responses above, it is clear that the reasons that companies (in the sample respondent group) provide CSR disclosures, relate to a combination of altruistic and instrumentalist reasons. Interestingly, even in where the majority of respondents did not agree with the assertion, they tended to be neutral, neither agreeing nor disagreeing. In fact, the highest rate of disagreement to any of the assertions was only five (13\%). It is, however, expected that as CSR becomes more embedded into corporate practice, respondents will become more aware of its impact, resulting in the quality of responses to similar questions improving even further.

\section{Research limitations}

It is acknowledged that confining the study to a purposively selected sample of the largest 200 JSE-listed companies, means that it cannot be considered to be representative. The observations therefore only apply to the selected companies, implying that the research results and conclusions are not generalisable and cannot be extrapolated to the population.

While certain companies combined the annual and/or CSR reports of their constituent companies into one report ( $\mathrm{n}=7$ ), others were new JSE listings and had not yet published annual reports at the date of review $(\mathrm{n}=4)$. The sample was accordingly adjusted to 189 companies. In total, 39 responses were received, representing a response rate of $21 \%$.

Moreover, the study recognises that possible respondent bias increases the risk that only respondents who were favourably predisposed to CSR disclosures, may have responded to the survey. Similarly, it may have been ignored by proponents of shareholder primacy. It is therefore possible that, not only do the survey results not represent the entire population, it may also not necessarily be representative of the sample either. Nevertheless, since this article represents an exploratory study, the inclusion of empirical data, albeit limited, provides important context to the study and is only intended to illustrate the reasons that companies adopt responsible CSR practices.

\section{Conclusion}

This article provides business academics, without any prior ethical or moral philosophical training, with an appreciation of the development and challenges of the ethics discourse resulting within the context of the emerging CSR phenomenon. This article has particular relevance for academics involved in accounting education that have historically been responsible for preparing aspirant accounting practitioners to report on financial performance, and may have to consider educating students on the reporting of non-financial performance, as well as to provide independent assurance thereon. While this article is not intended to provide a definitive treatise on CSR, the CSR concept is briefly introduced in order to provide the necessary contextual perspective.

The article introduces the paradigm shift required from the traditional role of corporations only being accountable to shareholders, to now being expected to account for triple bottom line performance as well. As stakeholders increasingly hold corporations accountable for the broader economic, social and environmental impacts of their operations, it is evident that corporations can no longer continue to remain morally intransigent about their CSR related performance. Corporations engage in responsible CSR practices in order to improve corporate risk management, enhance corporate financial performance, meet society's expectations of corporations and simply because 'it is the right thing to do'.

Being juristic bodies implies that corporations require natural persons to develop and implement corporate strategies. Implementing effective CSR practices requires individuals to demonstrate enlightened leadership. Extant corporate governance practice acknowledges that the board is responsible for developing corporate strategy, including the strategic CSR dimension. Similarly, global legislation and regulations hold the board accountable for ensuring effective corporate governance practices. These factors have resulted in developing a CSR approach that is driven by the philosophical perspective of the board and top management respectively. When CSR responsibility is relegated to lower levels within the corporation, it produces a rather superficial CSR approach that undermines the necessary buy-in throughout the corporation, to ensure effective implementation of CSR practices. To fully discharge this moral accountability, it is imperative that these CSR practices should consider the requirements of stakeholders.

Ethical principles fundamentally consider the difference between right and wrong, good and bad, or acceptable or unacceptable behaviour. Ethical decision-making is not simply a proverbial 'black or white' issue, but often requires making hard choices between more than one good or even less bad alternative. The different motivations for engaging in, and accounting for company CSR activities are illustrated by the various ethical models, which introduce some of the ethical dilemmas that corporations are presently grappling with. Given the information asymmetry caused by the agency problem and the fact that the board and management are responsible for implementing CSR practices, may result in dissonance between the morals, ethics and values of the responsible individuals. This ethical dissonance may bring the personal values of those responsible for governance and the requirements of the business, into conflict.

Two primary CSR motivations are considered. The first is 
economic CSR, as encapsulated in instrumentalism, in terms of which CSR is merely an instrument to serve shareholders" short-term interests. The second is ethical CSR, which considers CSR to be both socially desirable and morally commendable, by accounting for the impact of corporate activities within the context of legitimate stakeholder interests and expectations. The reality, however, is that the CSR approach of most corporations fall somewhere along a continuum representing the two extreme positions, requiring trade-offs between the interests of stakeholders and shareholders. Despite not presenting a definitive assessment of the reasons that corporations adopt a particular CSR position, the limited empirical data introduced in this article illustrates that the two motivations are not mutually exclusive, with both economic and ethical reasons being advanced for engaging in CSR practices.

In order to meaningfully deal with ethical CSR related dilemmas, corporate role players including the board, corporate management and employees, as well as CSR assurance providers to understand and appreciate the complexities and dynamics of the moral, ethical and value dimensions impacting their CSR decision-making. The need for role players to acquire the knowledge and skills necessary to discharge their CSR responsibilities is elevated by the King III requirement for corporations to not only be responsible corporate citizens, but also to demonstrate their accountability by reporting on their CSR performance and providing independent assurance thereon. Therefore, irrespective of whether companies adopt an ethical or unethical approach to CSR, it is clear that in order to deal with the complexity of emerging CSR challenges, corporate role players should be familiar with the fundamental moral, ethical and value dimensions.

\section{References}

Alexander, G.J. \& Buchholz, R.A. 1978. 'Corporate social responsibility and stock market performance', The Academy of Management Journal. 21(3): 479-486.

Allen, S. 2009. The new ROE: Return on ethics. Forbes Magazine, 21 July. Accessed online on 22 July 2009 at http://www.forbes.com/2009/07/21/business-culture-

corporate-citizenship-leadership-.

Aras, G. \& Crowther, D. 2009. 'Corporate sustainability reporting: A study in disingenuity?', Journal of Business Ethics. 87(1): 279-288.

Bansal, P. 2005. 'Evolving sustainability; A longitudinal study of corporate sustainable development', Strategic Management Journal. 26(3): 197-218.

Bebbington, J., Larrinaga, C. \& Moneva, J.M. 2008. Corporate social responsibility reporting and reputation risk management. Accounting, Auditing \& Accountability Journal. 21(3): 337-361.
Beekun, R.I., Stedham, Y. \& Yamamura, J.H. 2003. 'Business ethics in Brazil and the U.S.: A Comparative investigation', Journal of Business Ethics. 42(3): 267-279.

Berliant, L. 2009. Hunter Lovins makes the business case for climate protection. Solve Climate News, 23 June 2009 , accessed online on 17 January 2011 at http://solveclimatenews.com/news/20090623/hunter-lovinsmakes-business-case-climate-protection.

Black, L. \& Quach, A. 2009. "Long-term business success through corporate responsibility", White paper: Australian Centre for Corporate Social Responsibility [ACCSR] and SAI Global.

Brammer, S., \& Millington, A. 2008. 'Does it pay to be different? An analysis of the relationship between corporate social and financial performance', Strategic Management Journal. 29(12): 1325-1343.

Cacioppe, R., Forster, N. \& Fox, M. 2008. 'A survey of managers' perceptions of corporate ethics and social responsibility and actions that may affect companies' success', Journal of Business Ethics. 82(3): 681-700.

Carroll, A.B. 1991. 'The pyramid of corporate social responsibility: toward the moral management of organisational stakeholders", Business Horizons. 34(4): 3948.

Coker, E.W. 1990. 'Adam Smith's concept of the social system', Journal of Business Ethics. 9(2): 139-142.

Cowan, N. 2004. Corporate governance that works! Singapore: Prentice Hall.

De Cremer, D., van Dick, R., Tenbrunsel, A., Pillutla, M. \& Murnighan, J.K. 2011. 'Understanding ethical behavior and decision making in management: A behavioural business ethics approach ${ }^{*}$, British Journal of Management. 22(Supplement): s1-s4.

Donaldson, T. \& Dunfee, T.W. 1994. 'Toward a unified conception of business ethics: Integrative social contracts theory". Academy of Management Review. 19(2): 252-284.

Eccles, N.S., Pillay, V. \& De Jongh, D. 2008. 'Correlates of corporate accountability amongst South Africa's largest listed companies', Southern African Business Review. 13(1): $21-38$.

Elkington, J. 1999. Cannibals with forks - The triple bottom line of $21^{\text {st }}$ century business. Oxford, UK: Capstone.

Freeman, R.E. 1984. Strategic management: A stakeholder approach. Boston, USA: Pitman/Ballinger.

Friedman, M. 1970, 'The social responsibility of business is to increase its profits', The New York Times Magazine, 13 September, 1970. 
Graves, S.B. \& Waddock, S.A. 1994. 'Institutional owners and corporate social performance', The Academy of Management Journal. 37(4): 1034-1046.

Harper, S.J. 2009. 'Ethics versus morality: A problematic divide', Philosophy Social Criticism. 35(9): 1063-1077.

Hendrikse, J.W. \& Hendrikse, L. 2004. Business governance handbook - Principles and practice. Lansdowne, South Africa: Juta.

Institute of Chartered Accountants in England and Wales [ICAEW] 2004. Information for better markets Sustainability; The role of accountants. London, UK: ICAEW.

Institute of Directors [IoD] 2009. King Code of Governance for South Africa 2009. Sandton, South Africa: LexisNexis.

Jenkins, R. 2001, Corporate codes of conduct: Selfregulation in a global economy. Technology, Business and Society, Programme Paper no. 2: April 2001. Geneva, Switzerland: United Nations Research Institute for Social Development [UNRISD].

Johannesburg Stock Exchange (JSE). 2011. JSE listing requirements. Service issue 14, 25 November. Accessed online on 28 January 2012 at http://www.jse.co.za/Libraries/JSE___Listings

Requirements__Service_Issues/Service_Issue_14.sflb.ashx.

Kirk, R. 2008. The old future is gone. Forbes.com. Accessed online on 3 Mareh 2008 at http://www. forbes.com/2008/01/04/environment-kirkcorporate-lead-citizen-cx_vk_0104sustainability.html? partner $=$ relatedstoriesbox

Kok, P., van der Wiele, T., McKenna, R. \& Brown, A. 2001. ${ }^{4} A$ corporate social responsibility audit within a quality management framework, Journal of Business Ethics. 31(4): 285-297.

KPMG 2008. KPMG International survey of corporate responsibility reporting 2008. Amsterdam, the Netherlands: KPMG Sustainability Services.

Leedy, P.D. \& Ormrod, J.E. 2005, Practical research planning and design. $8^{\text {th }}$ Edition. Upper Saddle River, New Jersey, USA: Pearson Education.

Maignan, I., Ferrell, O.C. \& Hult, G.T.M. 1999. 'Corporate citizenship: Cultural antecedents and business benefits', Journal of the Academy of Marketing Sciences. 27(4): 455469.

Mill, G.A. 2006. 'The financial performance of a socially responsible investment over time and a possible link with corporate social responsibility', Journal of Business Ethics. 63(2):131-148.
Moon, J., Crane, A. \& Matten, D. 2003. 'Can corporations be citizens? Corporate citizenship as a metaphor for business participation in society", $2^{\text {nd }}$ Edition. ICCSR Research Paper Series - ISSN 1479-5124; No. 13-2003. Nottingham, UK: Nottingham University.

Morimoto, R., Ash, J. \& Hope, C. 2005. Corporate social responsibility audit: From theory to practice. Journal of Business Ethics, 62(4); 315-325.

Orlitzky, M., Schmidt, F.L. \& Rynes, S.L. 2003. 'Corporate social and financial performance: A meta-analysis', Organisation Studies. 24(3): 403-441.

Pesqueux, Y. 2009. "Sustainable development: A vague and ambiguous theory', Society and Business Review. 49(3): $231-245$.

Reuvid, J. 2007. Managing business risk - A practical guide to protecting your business. $4^{\text {th }}$ Edition. London, UK: Kogan Page.

Ryghaug, M., Sørensen, K.H. \& Næss, R, 2011. 'Making sense of global warming; Norwegians appropriating knowledge of anthropogenic climate change', Public Understanding of Science. 20(6): 778-795.

Sadler, D. \& Lloyd, S. 2009. "Neo-liberalising corporate social responsibility: A political economy of corporate citizenship " Geoforum, 40(4): 613-622.

Statman, M. 2000. 'Socially responsible mutual funds', Financial Analysts Joumal. 56(3); 30-39.

Stead, W.E., Worrell, D.L. \& Stead, J.G. 1990. 'An integrative model for understanding and managing ethical behavior in business organizations', Journal of Business Ethics. 9(3): 233-242.

Sunter, C. 1996. The high road: Where are we now? Cape Town, South Africa: Human \& Rousseau Tafelberg.

von der Pfordten (2012), 'Five elements of normative ethics - A general theory of Normative individualism', Ethical Theory and Moral Practice. 15(4): 449-471.

Waddock, S.A. \& Graves, S.B. 1997. 'The corporate social performance - financial performance link', Strategic Management Journal. 18(4); 303-319.

Wan-Jan, W. S. 2006. 'Defining corporate social responsibility', Journal of Public Affairs. 6(3-4): 176-184.

Warren, R.C. 2011. 'Are we making progress in international business ethics?', Humanomics. 27(3): 212224.

Wartzman, R. 1987. 'Nature or nurture? Study blames ethical lapses on corporate goals', The Wall Street Journal, $9^{\text {th }}$ October 1987. 
Welman, C., Kruger, F. \& Mitchell, B. 2011. Research Methadology. $3^{\text {rd }}$ Edition, $10^{\text {th }}$ impression. Goodwood, South Africa: Oxford University Press Southern Africa.

Windsor, D. 2006. 'Corporate sôcial responsibility: Three key approaches', Journal of Management Studies, 43(1):93114.

Wines, W.A. 2008. 'Seven pillars of business ethics: Towards a comprehensive framework', Journal of Business Ethics. 79(4): 483-499.

Winn, M.I., Kirchgeorg, M., Griffiths, A. Linnenluecke, M.K. \& Günther, E. 2011. 'Impacts from climate change on organizations: A conceptual foundation', Business Strategy and the Environment. 20(3): 157-173.

Yuhei, I., Aubrey, K. \& Seoki, L. 2011. 'CSR and the bottom line: Analyzing the link CSR and financial performance for professional teams', Joumal of Sport Management. 25(6): 531-549.

Zenisek, T.J. 1979. 'Corporate social responsibility: A conceptualization based on organisational literature', The Academy of Management Review, 4(3): 359-368. 